\begin{tabular}{|c|c|c|c|c|c|c|}
\hline \multirow{4}{*}{ Impact Factor: } & ISRA (India) & $=3.117$ & SIS (USA) & $=0.912$ & ICV (Poland) & $=6.630$ \\
\hline & ISI (Dubai, UAE & $=0.829$ & РИНЦ (Russia & $=0.156$ & PIF (India) & $=1.940$ \\
\hline & GIF (Australia) & $=0.564$ & ESJI (KZ) & $=8.716$ & IBI (India) & $=4.260$ \\
\hline & JIF & $=1.500$ & SJIF (Morocco & $=5.667$ & OAJI (USA) & $=0.350$ \\
\hline
\end{tabular}

\begin{tabular}{|c|c|}
\hline \multicolumn{2}{|c|}{$\begin{array}{l}\text { SOI: } \frac{1.1 / \mathrm{TAS}}{\mathrm{TOI}} \underline{10.15863 / \mathrm{TAS}} \\
\text { International Scientific Journal } \\
\text { Theoretical \& Applied Science }\end{array}$} \\
\hline p-ISSN: 2308-4944 (print) & e-ISSN: 2409-0085 (online) \\
\hline Year: 2019 & Volume: 71 \\
\hline Published: 29.03 .2019 & http://T-Science.org \\
\hline
\end{tabular}

SECTION 31. Economic research, finance, innovation, risk management.
QR - Issue

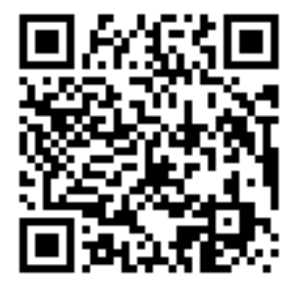

QR - Article

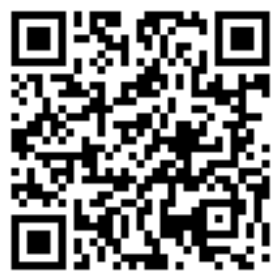

Ibrokhim Habibullaev

Professor,

Tashkent Financial Institute,

Tashkent, Republic of Uzbekistan

Markhabo Habibullo qizi Saidova

PhD student,

Tashkent State University of Economics,

Tashkent, Republic of Uzbekistan

\title{
EMBEDDEDNESS AND GROWTH OF BUSINESS IN UZBEKISTAN
}

Abstract: This article refers to the theoretical and practical aspects of business, its development paths and strategy selection in Uzbek economy, the statistical analyses through methods of observation, collection of statistical data, classification, tabulation; and also diagrams and graphs frequently used in presenting data, dynamic changes, comparison and prognosis of indicators of the development of business, including the ways of improvement of private sector in the formation of economy as well as the perspectives of development of business in Uzbekistan.

Key words: business, competitiveness, productivity, innovation, micro firm, privatization, family business, individual business, small business, statistical analyses of data, analytical method, prognosis.

Language: English

Citation: Habibullaev, I., \& Saidova, M. H. (2019). Embeddedness and growth of business in Uzbekistan. ISJ Theoretical \& Applied Science, 03 (71), 441-447.

Soi: http://s-o-i.org/1.1/TAS-03-71-36 Doi: rossef https://dx.doi.org/10.15863/TAS.2019.03.71.36

\section{Introduction}

In today's highly competitive world, we cannot imagine economic development of country without business which is considered to be one of the main sectors as fast growing economy and improving living standards in national economy. Through developing of these sectors new jobs are created, productivity and competitiveness are increased, poverty are alleviated and societal goals are achieved, in particular by helping specific population groups to help themselves.

Business plays a crucial role in the formation and development of Uzbek economy. Since its independence the republic of Uzbekistan, which is a doubly landlocked country conducted enormous economic changes. Economic reform has been gradually increased throughout many areas, such as business. As stressed by The First President of the Republic of Uzbekistan I.A.Karimov "Measures to improve the business environment and create more favorable conditions for the development of small business and private entrepreneurship deserve all kind of support'[1]

Moreover, business plays a distinctive and irreplaceable role in the development of the economy in Uzbekistan. Through developing of these sectors is provided with creating new jobs, increasing productivity and competitiveness, alleviating poverty and achieving societal goals. Uzbek economy operates two types of enterprises, which are large and small enterprises, as well as the activities depend on personal and family labor. The condition to run a business in Uzbekistan has been implemented through the Law of the Republic of Uzbekistan "On family business", "On the introduction of amendments and additions" in the Law of the Republic of Uzbekistan, "On guarantees of free entrepreneurial activity " and they are designed to further facilitate the development of business.

According to the Decree of the President of the republic of Uzbekistan the law "On measures to further stimulation of business development" the subjects of Business divided into three parts:

1) Individual business-is physical person without legal entity;

2) Micro firm- employing 20 people or fewer people in production, 10 people or fewer in services, 5 people or fewer in trade (retail and wholesale);

3) Small business. A firm was considered "small" for the purposes of tax collection if the number of employees did not exceed an officially 


\begin{tabular}{|c|c|c|c|c|c|c|}
\hline \multirow{4}{*}{ Impact Factor: } & ISRA (India) & $=3.117$ & SIS (USA) & $=0.912$ & ICV (Poland) & $=6.630$ \\
\hline & ISI (Dubai, UAE & $=0.829$ & РИНЦ (Russia & $=0.156$ & PIF (India) & $=1.940$ \\
\hline & GIF (Australia) & $=0.564$ & ESJI (KZ) & $=8.716$ & IBI (India) & $=4.260$ \\
\hline & JIF & $=1.500$ & SJIF (Morocco & $=5.667$ & OAJI (USA) & $=0.350$ \\
\hline
\end{tabular}

established limit of 200 people (to July 1, 2014 was 100 people) in heavy industry and construction, 25 in Research and science, 20 in other areas of production, 10 in trade and services. [4, 11,12,13]

The official definition of small businesses has changed a few times. The law "On measures to further stimulation of business development" currently regulates all activity of the business sector.

\section{Methodology and Results}

\subsection{Data}

The statistical data has been taken from the official website and reports of The State Commitee of Uzbekistan. All used data in this article describe the share of business in GDP, in the number of employed, in the volume of production of agricultural products and exports of the Republic of Uzbekistan during the period 2000-2016.

Researchers in field of textile small business was researched by economists as well as Boltabaev B., Kryvyakin K., Hakimov Z., Tursunov B. [14-20] and others.

In readiness of this article there have been extensively used methods of observation, collection of statistical data, classification, tabulation; and also diagrams and graphs frequently used in presenting data, dynamic changes, comparison and prognosis of indicators of the development of business.

\subsection{Descriptive statistics}

As the matter of fact, according to the governmental report, the GDP of the Republic of Uzbekistan for 2017 in current prices amounted to 249136.4 billion sums and grew by $5.3 \%$ relative to the corresponding period of 2016. The index-deflator of GDP in relation to the prices of 2016 amounted to $118.9 \%$.

At the end of 2017, GDP per capita amounted to 7.092 million sums, which is $3.6 \%$ more than last year. The largest contribution to GDP growth was made by the services sector, which grew by $6.9 \%$ compared to the previous year. Of this, trade, including accommodation and food services, grew by $3.9 \%$, transportation and storage, information and communication - by $8.9 \%$ and other services - by $7.3 \%$.

The added value of the industry showed an increase of $4.6 \%$, which was $26.7 \%$ in the GDP structure. A positive contribution to GDP growth from industrial production is estimated at $1.1 \mathrm{pp}$. Growth in the industry as a whole is ensured by the growth of the added value of the mining industry and quarrying (114.6\%) and manufacturing (102.8\%).

As a result of ongoing large-scale construction of multi-apartment residential buildings, individual housing for standard projects, engineering and transport communications, social infrastructure facilities, etc., the increase in the volume of construction work was $5.6 \%$. In the structure of GDP, the share of construction amounted to $6.8 \%$. A positive contribution to GDP growth from the construction sector is estimated at $0.4 \mathrm{pp}$.

In January-June of 2018 , the share of small business in the GDP was $49,2 \%(54,3 \%$ in JanuaryJune 2017). This decrease is due to the increase in the share of large enterprises in the GDP structure. Regionally, the largest share of small business in the GRP falls on the Jizzakh $(73,5 \%)$, Surkhandarya $(72,9 \%)$, Bukhara $(71,1 \%)$ and Namangan $(69,6 \%)$. In Navoi region this indicator remains low and is equal to $31,2 \%$. In the regional context, the largest share of small business in industry was registered in Tashkent $(68,0 \%)$, Namangan $(63,7 \%)$ and Jizzakh $(60,8 \%)$ regions. In construction - in Samarkand (98,8\%), Jizzakh (98,3\%), Andijan $(97,5 \%)$ and Syrdarya $(95,0 \%)$ regions. In the sphere of services - in Samarkand (75,0\%), Tashkent $(74,5 \%)$, Fergana and Bukhara $(74,2 \%)$, Surkhandarya $(72,9 \%)$, Andijan $(72,2 \%)$.

It is admitted that, the share of business in GDP is increasing year by year. As you can see below, the bar chart represents growing trend of share of business development from 2005 to 2017. 


\begin{tabular}{|c|c|c|c|c|c|c|}
\hline \multirow{4}{*}{ Impact Factor: } & ISRA (India) & $=\mathbf{3 . 1 1 7}$ & SIS (USA) & $=0.912$ & ICV (Poland) & $=6.630$ \\
\hline & ISI (Dubai, UAE & $=0.829$ & РИНЦ (Russia & $=0.156$ & PIF (India) & $=1.940$ \\
\hline & GIF (Australia) & $=0.564$ & ESJI (KZ) & $=8.716$ & IBI (India) & $=4.260$ \\
\hline & JIF & $=1.500$ & SJIF (Morocce & $=5.667$ & OAJI (USA) & $=0.350$ \\
\hline
\end{tabular}

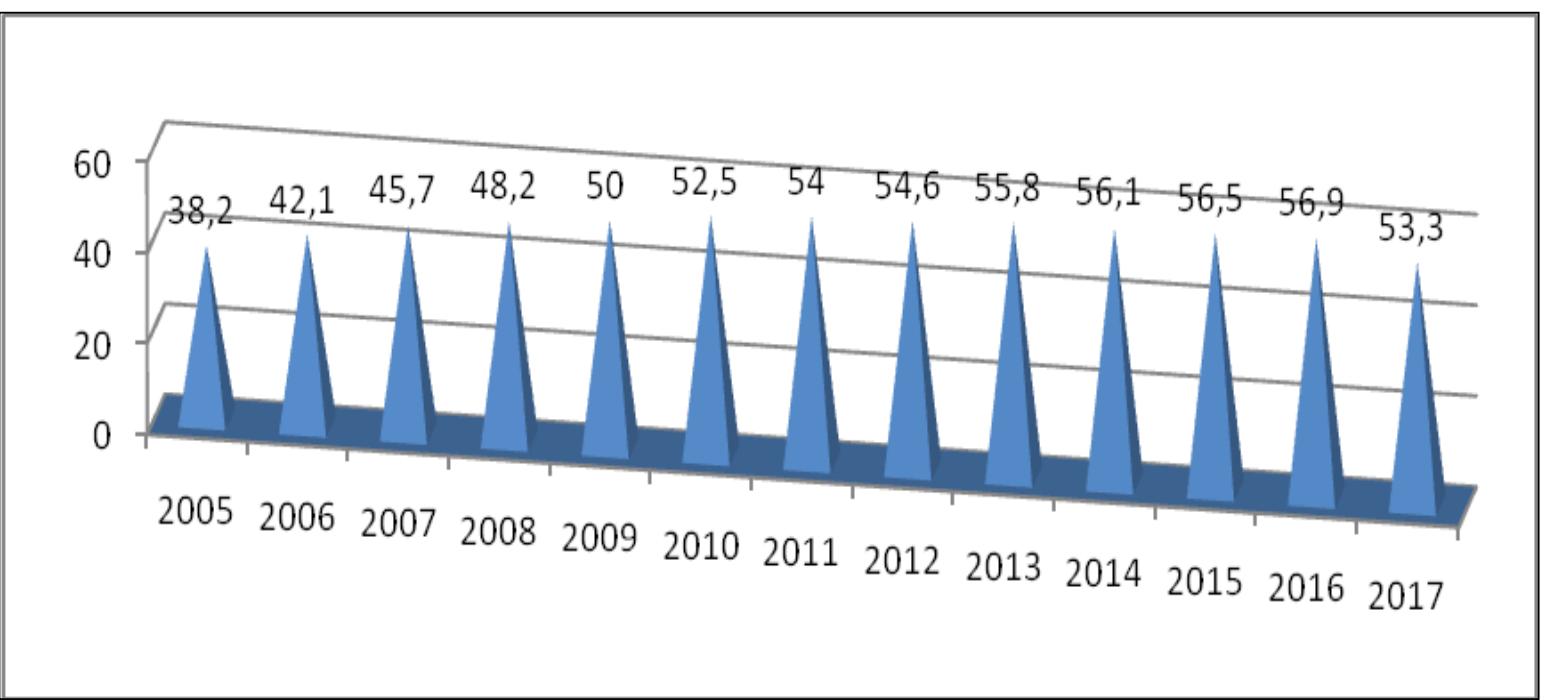

Graph 1.[3] The share of business in 2010-2016 GDP in Uzbekistan (in percent).

Source: The data are taken from the official website of "The State Committee of the Republic of Uzbekistan on Statistics"

The chart has shown the contribution of business in GDP year by year. In 2005, business share amounted to $38,2 \%$ and in 2017 it reached 53,3\%. Although this rate decreased in 2017 compared with last year. This is related to facts.

The message of the Committee says that in 2016 the share of business in total volume of industrial production amounted to $45 \%$ (in $2015-40,68 \%$ ), in retail turnover $-89,6 \%(87.1 \%)$, and in employment $-78,1 \%(77.9 \%)$. [2]

\begin{tabular}{r|crc} 
Source & SS & df & MS \\
\hline Model & 1381.40638 & 2 & 690.703189 \\
Residual & 60.0089163 & 14 & 4.28635116 \\
\hline Total & 1441.41529 & 16 & 90.0884559
\end{tabular}

2.3 OLS model to test the significances of the relationships of the share of business in Uzbekistan

The main aim of this paper is create appropriate model and explain the meaning of the relationships. In this way taking into account specific features of our country I prefer to present two models. The former is ordinary least squares model, the latter is analytical method to prognosis for perspective data.

OLS model is also found appropriate to the business development in Uzbekistan. Here to change the share of business in GDP, the share of business in the number of employed, in the volume of production of agricultural products and exports are affected.

$$
\begin{array}{lr}
\text { Number of obs } & =17 \\
\mathrm{~F}(2,14) & =161.14 \\
\text { Prob }>\mathrm{F} & =0.0000 \\
\text { R-squared } & =0.9584 \\
\text { Adj R-squared } & =0.9524 \\
\text { Root MSE } & =2.0704
\end{array}
$$

\begin{tabular}{r|rrrrrr}
\hline A & Coef. & Std. Err. & $t$ & $\mathrm{P}\rangle|\mathrm{t}|$ & [95\% Conf. Interval] \\
\hline B & .7053432 & .0788269 & 8.95 & 0.000 & .5362764 & .87441 \\
$D$ & .3849834 & .1106778 & 3.48 & 0.004 & .1476031 & .6223637 \\
\hline Cons & -7.808183 & 4.328464 & -1.80 & 0.093 & -17.09181 & 1.475449
\end{tabular}

Table 1. OLS regression results of the model for the development of business in Uzbekistan. Note: The results are calculated with STATA 13. 


\begin{tabular}{|c|c|c|c|c|c|c|}
\hline \multirow{4}{*}{ Impact Factor: } & ISRA (India) & $=3.117$ & SIS (USA) & $=0.912$ & ICV (Poland) & $=6.630$ \\
\hline & ISI (Dubai, UAE & $=0.829$ & РИНЦ (Russia) & $=0.156$ & PIF (India) & $=1.940$ \\
\hline & GIF (Australia) & $=0.564$ & ESJI (KZ) & $=8.716$ & IBI (India) & $=4.260$ \\
\hline & JIF & $=1.500$ & SJIF (Morocco) & $=5.667$ & OAJI (USA) & $=0.350$ \\
\hline
\end{tabular}

From this Table 1 we can see that all regression coefficients are statistically significant, except the share of business in the volume of production of agricultural products. In further we use analytical method in dynamic lines to predict future events.

2.4 Analytical method about long-range prognosis of business development in Uzbekistan

A prediction is a statement about a risk. It is often based upon experience or knowledge and it can be useful to assist in making decisions about possible developments. Howard H. Stevenson writes that prediction in business is at least two things: important and hard.

In statistics, prediction is a part of inference. One particular approach to such inference is known as predictive inference, but the prediction can be undertaken within any of the several approaches to statistical inference. Indeed, one description of statistics is that it provides a means of transferring knowledge about a sample of a population to the whole population, and to other related populations, which is not necessarily the same as prediction over time. When information is transferred across time, often to specific points in time, the process is known as forecasting.

In many applications, such as time series analysis, it is possible to estimate the models that generate the observations. If models can be expressed as transfer functions or in terms of state-space parameters then smoothed, filtered and predicted data estimates can be calculated.

In order to use analytical method for prediction, data are collected on the variable that is to be predicted. A functional form, often linear the parameters of the function are estimated from the data that are chosen so as to optimize is some way the fit of the function to the data. For the prediction step, explanatory variable values that are deemed relevant to future values of the dependent variable are input to the parameterized function to generate predictions for the dependent variable.

We know, through analytical method we can predict future events. Necessary information is given below:

Table 1. Results theoretical aspects of business share in GDP for observing period.

\begin{tabular}{|c|c|c|c|c|c|}
\hline Years & $\mathrm{Y}_{\mathrm{i}}$ & $t$ & $t^{2}$ & $Y_{i^{*} t}$ & $Y_{t}$ \\
\hline 2010 & 52,5 & -3 & 9 & $-157,5$ & 53,021 \\
\hline 2011 & 54,0 & -2 & 4 & $-108,0$ & 53,664 \\
\hline 2012 & 54,6 & -1 & 1 & $-54,6$ & 54,307 \\
\hline 2013 & 55,8 & 0 & 0 & 55,8 & 55,593 \\
\hline 2014 & 56,1 & 1 & 1 & 112,2 & 56,236 \\
\hline 2015 & 56,7 & 2 & 4 & 170,1 & 56,879 \\
\hline 2016 & 56,9 & 3 & 9 & 170,7 & 56,985 \\
\hline$\Sigma$ & 329,7 & & & & 329,7 \\
\hline
\end{tabular}

In order to use analytical method we need right linear equation. Here its mathematical formula:

$$
\overline{\boldsymbol{Y}}_{t}=\mathbf{a}_{0}+\mathbf{a}_{1} \mathbf{t}
$$

In this, t-periods; $\mathrm{a}_{0}$ and $\mathrm{a}_{1}$

$$
\left\{\begin{array}{l}
\mathbf{a}_{0} \mathbf{n}+\mathbf{a}_{1} \sum \mathbf{t}=\sum \mathbf{y} \\
\mathbf{a} \mathbf{0} \sum \mathbf{t}-\mathbf{a}_{1} \sum \mathbf{t}^{2}=\sum \mathbf{y t}
\end{array}\right.
$$

Here, y-real degree of lines; and n-the number of degree.

$$
\begin{aligned}
& \mathbf{a}_{0}=\overline{\mathbf{y}}-\mathbf{a}_{1} \mathbf{t} \quad \text { and } \quad \mathbf{a}_{0}=\frac{\sum \mathbf{y}}{n}-\mathbf{a}_{1} \frac{\sum \mathbf{t}}{\mathbf{n}}, \text { after that } \\
& \mathbf{a}_{\mathbf{0}}=\frac{\mathrm{n} \sum \mathbf{y t}-\sum \mathbf{t} \sum \mathbf{y}}{\mathrm{n} \sum \mathbf{t} \mathbf{2}-\left(\sum \mathbf{t}\right) \mathbf{2}} ;
\end{aligned}
$$

If $\sum \mathrm{t}=0$, then the equation above can be in that manner:

$$
\left\{\begin{array}{c}
\mathbf{a}_{0} \mathbf{n}=\sum \mathbf{y}, \\
\mathbf{a}_{1} \sum \mathbf{t}^{2}=\sum \mathbf{y t}
\end{array}\right.
$$

First of all, it is needed to be identified $\mathrm{a}_{0}$ and $\mathrm{a}_{1}$ ; for that purpose we have to calculate $\sum \mathrm{y}, \sum \mathrm{t}^{2}, \sum \mathrm{yt}$.
According to certain information these parameters are the following sequence: $a_{0}=\frac{\sum y}{n}=\frac{329,7}{6}=54,95$ and $\mathbf{a}_{1}=\frac{\sum \mathrm{yt}}{\sum \mathrm{t} \mathbf{2}}=\frac{18,0}{28,0}=\mathbf{0 , 6}$

To measure tendency of business I decided to use analytical method, which is one of the main methods to analyze economic changes in dynamic lines in statistics. Analytical methods welcome early applied demonstrations of new analytical methods. This method should be demonstrated that methods and technology are sufficiently fit for purpose in the future.

In this example, analytical method about longrange prognosis of business development in Uzbekistan characterized by the following graph and it is predicted through zoom lines how recent 


\begin{tabular}{|c|c|c|c|c|c|c|}
\hline \multirow{4}{*}{ Impact Factor: } & ISRA (India) & $=3.117$ & SIS (USA) & $=0.912$ & ICV (Poland) & $=6.630$ \\
\hline & ISI (Dubai, UAE & $=0.829$ & РИНЦ (Russia & $=0.156$ & PIF (India) & $=1.940$ \\
\hline & GIF (Australia) & $=0.564$ & ESJI (KZ) & $=8.716$ & IBI (India) & $=4.260$ \\
\hline & JIF & $=1.500$ & SJIF (Morocco & $=5.667$ & OAJI (USA) & $=0.350$ \\
\hline
\end{tabular}

economic trend may play out over the next few decades:

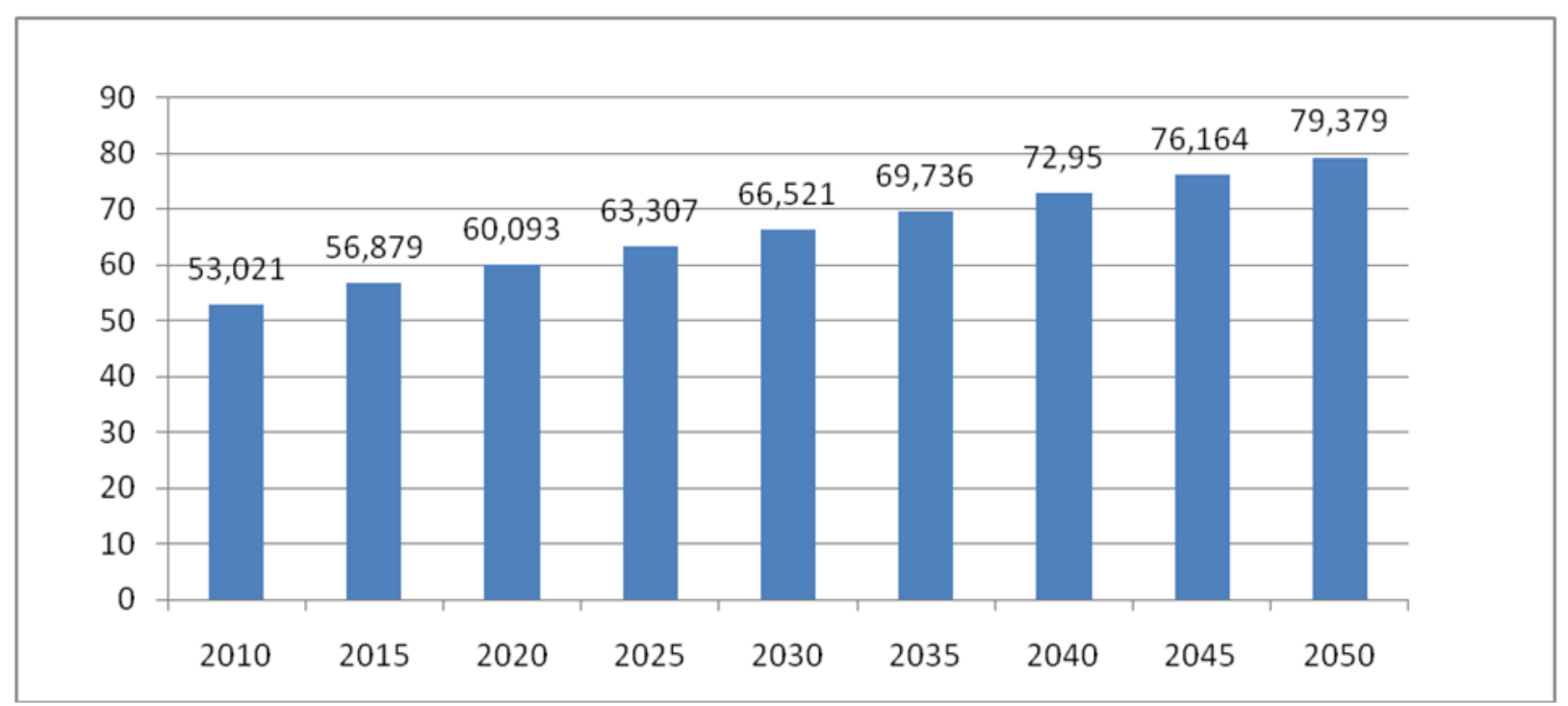

Graph 2. The prognosis of business share in Gross Domestic Product in Uzbekistan

Calculated by author through using information Business in Uzbekistan. Statistical Bulletin. Tashkent 2016

The bar chart illustrates the percentage of business in GDP in Uzbekistan from 2010 until 2050. It shows both present and future trend. Over the following five years, the share of business increased slightly from 53,0 per cent in 2010 to 56,8 per cent in 2015. As can be seen, every five year the growth rate has raised three or four per cent and the share is expected to go up modestly. Between 2015 and 2050, it is also projected to raise, but more steadily and it is predicted to reach more than three quarters in 2050 and then it will soar gradually.

\section{Conclusion and Recommendations}

Business more flexible and can adapt quickly to changes in demand, the situation on the global and regional markets, timely respond to their challenges, because it's compact in form, has a mobility and speed in decision-making and it's receptive to innovation. Creating and develop business do not require large expenditures and capital investments, which allows faster and easier to carry out modernization, technical and technological equipment, develop new products, constantly updating its range and provide competitiveness. The higher stability of this sector compared with large enterprises to the challenges and consequences of the global financial and economic crisis. Business are not only a source of income, but also opportunity to disclosure the creative and intellectual abilities of people. This scope allows everyone to show their individual talents and capabilities, thereby forming a new layer of people - enthusiastic, enterprising and prone to self-employment who can achieve the goal.
The most important document accepted by the Central Bank of the Republic of Uzbekistan jointly with the Association of Banks of Uzbekistan, commercial banks and international financial institutions is the development of foreign funds and banks, proposals for the creation of the Guarantee Fund. It provides for business the need for the part uncovered collateral for loans of commercial banks issued for the purchase of new equipment.

The higher stability of this sector compared with large enterprises to the challenges and consequences of the global financial and economic crisis. Business is not only a source of income, but also opportunity to disclosure the creative and intellectual abilities of people. This scope allows everyone to show their individual talents and capabilities, thereby forming a new layer of people - enthusiastic, enterprising and prone to self-employment who can achieve the goal.

As stressed by the President, "We should be aware that what has been achieved so far is just the beginning of the long path that the country has chosen: to become a modern, developed, democratic country; to ensure a decent quality of life for the people and for future generations; and to achieve a strong reputation in the international community". [5]

Opportunities of various strata of the population in taking advantage of benefits of economic growth also directly depend on infrastructure conditions. Infrastructure services are not only the major consumer benefits but also are means for increase of labour productivity and improvement of market access. Both functions of infrastructure - support of economic growth and expansion of its facilities- has a great importance for overcoming poverty, 


\begin{tabular}{|c|c|c|c|c|c|c|}
\hline \multirow{4}{*}{ Impact Factor: } & ISRA (India) & $=3.117$ & SIS (USA) & $=0.912$ & ICV (Poland) & $=6.630$ \\
\hline & ISI (Dubai, UAE & $=0.829$ & РИНЦ (Russia) & $=0.156$ & PIF (India) & $=1.940$ \\
\hline & GIF (Australia) & $=0.564$ & ESJI (KZ) & $=8.716$ & IBI (India) & $=4.260$ \\
\hline & JIF & $=1.500$ & SJIF (Morocco & $=5.667$ & OAJI (USA) & $=0.350$ \\
\hline
\end{tabular}

accumulating human capital, and increasing the welfare of the country.

Taking into account national peculiarities and spiritual values of the republic, entrepreneurship has a special social significance. Social efficiency reflects the degree of achievement of the social dimensions of entrepreneurship. In this case brings to the fore the question of how data with limited resources to best meet the needs of staff entrepreneurial structures (micro level) and all members of society (macro level).

Recommendations will be in the further development of business in Uzbekistan:

- Reduction of government intervention and regulatory authorities in the financial and economic activities of businesses;

- Creation of maximum favorable conditions, privileges and preferences on tax and other payments for business, improvement and standardization of the reporting system and the mechanism of delivery of reports in the financial, tax and statistical authorities;

- Broad involvement and direction for the development of business of foreign investment, especially concessional loans from international financial institutions and private equity;

- Further development of the information management system and advice to business, as well as in matters of training, retraining and skills development;

- Expand opportunities for small businesses bank loans, raw materials.

According to the idea of M.Kalecki who is Polish economist, the most important prerequisite for becoming an entrepreneur is the ownership of capital. In terms of prerequisite for business he was totally right. Nevertheless, it is also important entrepreneurial skills.

Needless to say, special initiatives to reduce burdens and support regulatory compliance of business should be balanced against other concerns. Business have been put forward and originally realized in industrially developed countries, but soon was picked up also in developing countries, which have experienced urgent need for expansion and modernization of infrastructure. The most important features are the ability of small businesses to accelerate the development of investment and high turnover of working capital. Another characteristic of this sector is an active innovation and accelerate the development of various sectors of the economy in all sectors of the Uzbek economy.

The inherent flexibility of small businesses and high adaptability to market conditions variability contribute to the stabilization of macro-economic processes in the country. Analysis showed that in Uzbekistan, the sector characterized by a certain yield, high labor intensity, the complexity of the introduction of new technologies, limited own resources, and increased risk of competition. In our view, it is appropriate to establish a definite system which provides for sanctions for clear violations or improper fulfillment of the law. A special role is played in business control over the implementation of legislation and economic reforms should be based on the full legal space. In this case, absolutely equal footing before the courts and arbitration authorities should be all. Uzbekistan has developed industry and regional priority programs and enterprise development are successfully implemented.

\section{References:}

1. (2015, January 16). In order to make more opportunities for development of private property and private enterprise through the implementation of the indigenous structural change in economy, a consistent continuation of the processes of modernization and diversification is our priority. President Islam Karimov's keynote speech at the meeting of the Cabinet of Ministers dedicated to the results of society-economic development of the country in 2014 and main priorities of economic program for 2015 .

2. (2017). Small business in Uzbekistan. Statistical Bulletin. (p.16). Tashkent.

3. (2017). Annual Statistical Report of Uzbekistan. Tashkent.
4. (2000). The Law of the Republic of Uzbekistan "On measures to further stimulation of business development" from May 25, 2000.

5. (2017, January 15). The year 2017 observed the continuation of active work on providing the reliable protection to private property, small business and private entrepreneurship, the removal of barriers to their rapid development. The Ministry of economy of the Republic of Uzbekistan has published a report on the results of society-economic development of the country in 2017 and the most important priorities of economic program for 2018.

6. Dutta, N., \& Sobel, R. S. (2018). Entrepreneurship and human capital: The role of financial development, International Review of 


\begin{tabular}{|c|c|c|c|c|c|c|}
\hline \multirow{4}{*}{ Impact Factor: } & ISRA (India) & $=3.117$ & SIS (USA) & $=0.912$ & ICV (Poland) & $=6.630$ \\
\hline & ISI (Dubai, UAE & $=0.829$ & РИНЦ (Russia & $=0.156$ & PIF (India) & $=1.940$ \\
\hline & GIF (Australia) & $=0.564$ & ESJI (KZ) & $=8.716$ & IBI (India) & $=4.260$ \\
\hline & JIF & $=1.500$ & SJIF (Morocco & $=5.667$ & OAJI (USA) & $=0.350$ \\
\hline
\end{tabular}

Economics and Finance. International Review of Economics and Finance Journal. doi: 10.1016/j.iref.2018.01.020.

7. Mueller, P. (2015). Exploiting Entrepreneurial Opportunities: The Impact of Entrepreneurship on Growth. The Small Business Economics Journal, 28, 355-362.

8. Leonidous, C. N., \& Hultman, M. (2018). Global marketing in business-to-business contexts: Challenges, developments, and opportunities Industrial Marketing Management Journal.

9. Coulibaly, S. K., Erbao, C., \& Mekongcho, T. M. (2018). Economic globalization, entrepreneurship and development. The Small Business Economics Journal.

10. Haghighi, N. F., Hajihoseini, H., Nargesi, G. R., \& Bijani, M. (2018). Gap analysis of current and desired states of entrepreneurship development components in the field of ICTs in Iran. The Small Business Economics Journal.

11. Tursunov, B. O. (2017). Methods of economic evaluation of reliability of textile enterprises in the conditions of market economy. In the collection: Theory and practice of industrial production. Efficiency of organization and management of industrial enterprises: problems and solutions Materials of the International scientific and practical conference. (pp.139144). Voronezh state technical University.

12. Ibragimov, I. U., \& Tursunov, B. O. Enhancement the mechanism of analyzing of the methodological principles for the development and improvement of methods of assessment. Audit, No. 4, 11-13.

13. Tursunov, B. O. (2017). The main directions of support of small business in Uzbekistan and foreign experience of development of entrepreneurship. Audit, No. 6, 34-38.

14. Tursunov, B. O. (2017). Development prospects of textile industry in Uzbekistan. Management in Russia and abroad, No. 4, 78-84.

15. Tursunov, B. O. (2017). Strategy of development of light industry of the republic of Uzbekistan. Bulletin of the Institute of Economics of the Russian Academy of Sciences, No. 5, 146-155.

16. Tursunov, B. O. (2017). Theoretical aspects of the production capacities of textile enterprises in modern conditions. Scientific-analytical journal Science and practice of the Russian University of Economics. G. V. Plekhanov, № 4 (28), 57-68.

17. Tursunov, B. O. (2017). Principles and functions of management of production capacity. Management Issues, № 3 (46), 174-178.

18. Tursunov, B. O. (2017). Inventory management in textile enterprises. Scientific thought, Vol.1, № 3 (25), 117-125.

19. Tursunov, B. (2017). Features of the method of calculation of the production capacities of textile enterprises. Bulletin of science and practice, № 10 (23), 213-222.

20. Tursunov, B. (2017). Ways of increasing the efficiency of usage of the production capacity of textile enterprises. Bulletin of science and practice, № 8 (21), 232-242. 